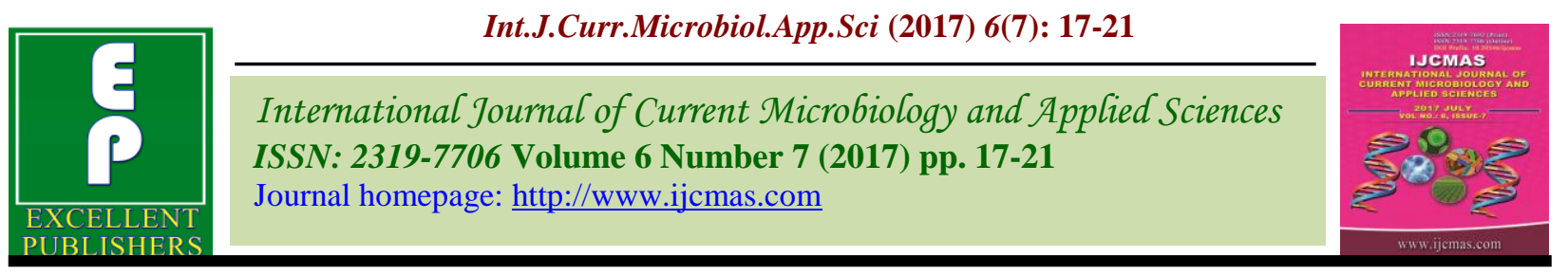

Original Research Article https://doi.org/10.20546/ijcmas.2017.607.003

\title{
Economics of Rice Varieties as Influenced by Combination of Plant Densities and Fertilizer Levels under Late Sown Conditions
}

\author{
O. Sampath* and A. Srinivas \\ Department of Agronomy, College of Agriculture, Prof. Jayashankar Telangana State \\ Agricultural University, Rajendranagar, Hyderabad-030, India \\ *Corresponding author
}

\section{A B S T R A C T}

\section{Keywords}

Economics,

Rice varieties,

Fertilizer and Sown conditions.

Article Info

Accepted:

04 June 2017

Available Online:

10 July 2017
A field experiment was conducted on a sandy clay loam soil at college farm of Professor Jayashankar Telangana State Agricultural University, Rajendranagar, Hyderabad, Telangana during the kharif seasons of 2014 and 2015 to study the economics of rice varieties as influenced by combination of plant densities and fertilizer levels under late sown conditions. Same cost of cultivation was recorded for the three varieties, MTU 1010, Rajendra and Pradyumna. Among the treatments the highest cost of cultivation was noticed with $\left(\mathrm{T}_{9}\right)$ viz., $\mathrm{P}_{3}(15 \mathrm{~cm} \times 10 \mathrm{~cm})$ in combination with $\mathrm{F}_{3}\left(195-86-90, \mathrm{~N}_{2} \mathrm{P}_{2} \mathrm{O}_{5}\right.$ and $\mathrm{K}_{2} \mathrm{O}$ ). The highest gross returns were recorded significantly by MTU 1010 over Rajendra and Pradyumna. Among the combination of planting density and fertility levels, the highest gross returns was recorded with the treatment $\left(\mathrm{T}_{9}\right)$ viz., $\mathrm{P}_{3}(15 \mathrm{~cm} \times 10 \mathrm{~cm})$ in combination with $\mathrm{F}_{3}\left(195-86-90, \mathrm{~N}, \mathrm{P}_{2} \mathrm{O}_{5}\right.$ and $\left.\mathrm{K}_{2} \mathrm{O}\right)$. It was on par with $\left(\mathrm{T}_{8}\right)$ viz., $\mathrm{P} 3(15 \mathrm{~cm}$ $\times 10 \mathrm{~cm})$ in combination with $\mathrm{F}_{2}\left(153-59-68, \mathrm{~N}, \mathrm{P}_{2} \mathrm{O}_{5}\right.$ and $\left.\mathrm{K}_{2} \mathrm{O}\right)$. The highest net returns (₹51595, 57974 and 54784 ha $^{-1}$ during 2014, 2015 and in pooled means, respectively) and $\mathrm{B}: \mathrm{C}$ ratio (1.30, 1.46 and 1.38 during 2014, 2015 and in pooled means, respectively.) were recorded by MTU 1010 over Rajendra and Pradyumna. Among the combination of planting density and fertility levels, the highest net returns were recorded with the treatment $\left(\mathrm{T}_{8}\right)$ viz., $\mathrm{P}_{3}(15 \mathrm{~cm} \times 10 \mathrm{~cm})$ in combination with $\mathrm{F}_{2}\left(153-59-68, \mathrm{~N}, \mathrm{P}_{2} \mathrm{O}_{5}\right.$ and $\left.\mathrm{K}_{2} \mathrm{O}\right)\left(₹ 57690,63864\right.$ and $\left.60777 \mathrm{ha}^{-1}\right)$. It was on par with $\left(\mathrm{T}_{9}\right)$ viz., $\mathrm{P} 3(15 \mathrm{~cm} \times 10 \mathrm{~cm})$ in combination with $\mathrm{F}_{3}\left(195-86-90, \mathrm{~N}, \mathrm{P}_{2} \mathrm{O}_{5}\right.$ and $\left.\mathrm{K}_{2} \mathrm{O}\right)$.

\section{Introduction}

Rice [Oryza sativa $(\mathrm{L}$.)] is one of the most important staple food crops in the world. However, more than 90 per cent of rice is consumed in Asia, where it is a staple food for a majority of the population, including the 560 million hungry people in the region (Mohanty, 2013). In Asia, more than two billion people are getting 60-70 per cent of their energy requirement from rice and its derived products. Among the rice growing countries, India has the largest area $(42.27 \mathrm{~m}$ ha) and it is the second largest producer $(105.24 \mathrm{~m} \mathrm{t})$ of rice next to China (144 m t). With an average productivity of $2.49 \mathrm{t} \mathrm{ha}^{-1}$, though increasing marginally, but is still well below the world's average yield of $4.36 \mathrm{tha}^{-1}$ (FAOSTAT Database, 2014). At the current population growth rate $(1.5 \%)$, the rice requirement of India by 2025 would be around $125 \mathrm{~m} \mathrm{t}$ (Kumar et al., 2009). The importance of continuing to develop new rice varieties to guarantee India's food security 
and support the region's economic development needs no special emphasis. Varieties play a vital role in maximizing of yield by improving the input use efficiency. The adverse effect of late transplanting can also be minimized by selecting suitable cultivar as magnitude of yield reduction varies with the rice cultivars. Plant population exerts a strong influence on the rice growth and grain yield, because of its competitive effects, both on the vegetative and reproductive development.

Optimum plant spacing ensures plants to grow properly both in their aerial and underground parts through utilization of solar radiation and nutrients, therefore proper manipulation of planting density may lead to increase in the economic yield of transplanted rice. Balanced fertilization right from the very beginning of crop growth is utmost essential to achieve better harvest of crop (Singh and Namdeo, 2004). Usually, rice yield declines when transplanting is delayed beyond the optimum time (Ologunde, 1987). The optimal date of transplanting of any field crop depends on the environmental conditions required for good growth and development. The farmer therefore seeks to manage the relationship between the crop and its environment in order to optimize growth and yield.

The present study is proposed to study the economics of rice varieties as influenced by combination of plant densities and fertilizer levels under late sown conditions.

\section{Materials and Methods}

Field experiment was conducted during the kharif season of 2014 and 2015 at Agricultural College Farm, Rajendranagar, Hyderabad. The experimental site was geographically situated at an altitude of 542.6 $\mathrm{m}$ above mean sea level, on $17^{0} 19^{1} \mathrm{~N}$ latitude and $78^{0} \quad 24^{1} \mathrm{E}$ longitude. It comes under Southern Telangana zone of Telangana. The soil was sandy clay loam in texture, neutral in reaction $(\mathrm{pH} 7.2$ ) with $0.49 \%$ of organic matter, with low available nitrogen $(180.8 \mathrm{~kg}$ $\mathrm{ha}^{-1}$ ), high available phosphorus (38.6 $\mathrm{kg} \mathrm{ha}^{-1}$ ) and potassium $\left(312 \mathrm{~kg} \mathrm{ha}^{-1}\right)$.

The experiments were laid out in a split plot design with three replications. Three varieties MTU 1010, Rajendra and Pradyumna as main plot treatments, three plant densities $\left(\mathrm{P}_{1}: 20 \mathrm{x}\right.$ $20 \mathrm{~cm}, \mathrm{P}_{2}: 15 \times 15 \mathrm{~cm}$ and $\left.\mathrm{P}_{3}: 15 \times 10 \mathrm{~cm}\right)$, three fertilizer levels $\left(\mathrm{F}_{1:}\right.$ : 111-32-45, $\mathrm{F}_{2:}$ : 15359-68 and $F_{3:}$ 195-86-90) as sub plot treatments.

The fertilizer levels111-32-45 $\mathrm{kg}$ NPK ha ${ }^{-1}$, 153-59-68kg NPK ha ${ }^{-1}$ and 195-86-90kg NPK $\mathrm{ha}^{-1}$ were applied as 50 per cent $\mathrm{N}$, full dose of $\mathrm{P}$ and 50 per cent $\mathrm{K}$ at the time of transplanting. Nitrogen was applied as per the treatments in 3 split doses as basal 50\% and at active tillering and panicle initiation stages $25 \%$ each. The remaining half of potassium was applied at panicle initiation stage.

\section{Gross returns $\left(₹ \mathrm{ha}^{-1}\right)$}

Gross returns were calculated by multiplying the grain and straw yield with their respective prevailing market prices (Perin et al., 1979) and presented as $₹ \mathrm{ha}^{-1}$.

\section{Net returns $\left({ }^{₹} \mathrm{ha}^{-1}\right)$}

The net returns were calculated by subtracting the cost of cultivation from the gross returns and presented as ₹ $\mathrm{ha}^{-1}$.

\section{Benefit:Cost ratio}

The benefit cost ratio (BCR) was worked out by using the following formula

$$
\text { Benefit:Cost ratio }=\frac{\text { Net returns }\left(₹ \mathrm{ha}^{-1}\right)}{\text { Cost of cultivation }\left(₹ \mathrm{ha}^{-1}\right)}
$$




\section{Results and Discussion}

\section{Gross returns}

Significant variations in grain and straw yields brought about variations in gross returns among varieties, combination of planting density and fertilizer levels during both the years of study (Table 1).

Among the varieties the highest gross returns were recorded significantly by MTU 1010 (₹91145, 97523 and $94334 \mathrm{ha}^{-1}$ during 2014, 2015 and in pooled means, respectively.) over Rajendra and Pradyumna. The lowest gross returns were obtained with Rajendra (₹75704, 80296 and 78000 ha $^{-1}$ during 2014, 2015 and in pooled means, respectively).

Among the combination of planting density and fertility levels, the highest gross returns (₹100368, 106096 and $103232 \mathrm{ha}^{-1}$ ) were recorded with the treatment $\left(\mathrm{T}_{9}\right)$ viz., $\mathrm{P}_{3}(15$ $\mathrm{cm} \times 10 \mathrm{~cm})$ in combination with $\mathrm{F}_{3}(195-86-$ $90, \mathrm{~N}, \mathrm{P}_{2} \mathrm{O}_{5}$ and $\mathrm{K}_{2} \mathrm{O}$ ) during 2014, 2015 and pooled means respectively.

It was on par with $\left(\mathrm{T}_{8}\right)$ viz., $\mathrm{P} 3(15 \mathrm{~cm} \times 10$ $\mathrm{cm})$ in combination with $\mathrm{F}_{2}$ (153-59-68, $\mathrm{N}$, $\mathrm{P}_{2} \mathrm{O}_{5}$ and $\mathrm{K}_{2} \mathrm{O}$ ) during 2014, 2015 and pooled means, respectively.

The lowest gross returns (₹63529, 67851 and $65690 \mathrm{ha}^{-1}$ during 2014, 2015 and in pooled means, respectively.) were obtained with $\left(\mathrm{T}_{1}\right)$ viz., $\mathrm{P}_{1}(20 \mathrm{~cm} \times 20 \mathrm{~cm})$ in combination with $\mathrm{F}_{1}\left(111-32-45, \mathrm{~N}, \mathrm{P}_{2} \mathrm{O}_{5}\right.$ and $\left.\mathrm{K}_{2} \mathrm{O} \mathrm{kg} \mathrm{ha}{ }^{-1}\right)$.

These results are in agreement with the findings of Swarna (2013) and Dakshina Murthy et al., (2015).

The interaction effect of varieties and plant density in combination with fertility levels during both the years and in pooled mean was found to be non-significant.

\section{Net returns}

Significant variations in grain and straw yields brought about variations in net returns among varieties, combination of planting density and fertilizer levels during both the years of study (Table 1).

Among the varieties the highest net returns was recorded significantly by MTU 1010 (₹51595, 57974 and 54784 ha $^{-1}$ during 2014, 2015 and in pooled means, respectively) over Rajendra and Pradyumna.

The increase was $26.04,42.7$ percent during 2014, it was 26.06, 42.3 percent during 2015 and $26.05,42.5$ percent in pooled means over Pradyumna and Rajendra respectively. The lowest net returns were obtained with Rajendra (₹36155, 40747 and $38451 \mathrm{ha}^{-1}$ during 2014, 2015 and in pooled means, respectively.)

Among the combination of planting density and fertility levels, the highest net returns $\left(₹ 57690, \quad 63864\right.$ and $\left.60777 \mathrm{ha}^{-1}\right)$ were recorded with the treatment $\left(\mathrm{T}_{8}\right)$ viz., $\mathrm{P}_{3}(15$ $\mathrm{cm} \times 10 \mathrm{~cm})$ in combination with $\mathrm{F}_{2}$ (153-59$68, \mathrm{~N}, \mathrm{P}_{2} \mathrm{O}_{5}$ and $\mathrm{K}_{2} \mathrm{O}$ ) during 2014, 2015 and pooled means, respectively. It was on par with ( $\left.\mathrm{T}_{9}\right)$ viz., $\mathrm{P} 3(15 \mathrm{~cm} \times 10 \mathrm{~cm})$ in combination with $\mathrm{F}_{3}$ (195-86-90, N, $\mathrm{P}_{2} \mathrm{O}_{5}$ and $\mathrm{K}_{2} \mathrm{O}$ ) during 2014, 2015 and pooled means, respectively. The lowest net returns (₹27070, 31392 and $29231 \mathrm{ha}^{-1}$ during 2014, 2015 and in pooled means, respectively.) were obtained with $\left(\mathrm{T}_{1}\right)$ viz., $\mathrm{P}_{1}(20 \mathrm{~cm} \times 20 \mathrm{~cm})$ in combination with $\mathrm{F}_{1}$ (111-32-45, N, $\mathrm{P}_{2} \mathrm{O}_{5}$ and $\mathrm{K}_{2} \mathrm{O} \mathrm{kg} \mathrm{ha}{ }^{-1}$ ). These results are in agreement with the findings of Swarna (2013), Dakshina Murthy et al., (2015).

The interaction effect of varieties and plant density in combination with fertility levels during both the years and in pooled mean was found to be non-significant. 
Table.1 Economics of rice varieties as influenced by combination of plant densities and fertilizer levels during kharif 2014, 2015 and pooled means

\begin{tabular}{|c|c|c|c|c|c|c|c|c|c|}
\hline \multirow{2}{*}{ Treatments } & \multicolumn{3}{|c|}{ Gross returns (₹ ha-1) } & \multicolumn{3}{|c|}{ Net returns $\left(₹ \mathrm{ha}^{-1}\right)$} & \multicolumn{3}{|c|}{$\mathrm{B}: \mathrm{C}$ ratio } \\
\hline & 2014 & 2015 & Pooled & 2014 & 2015 & Pooled & 2014 & 2015 & Pooled \\
\hline \multicolumn{10}{|c|}{ Main treatments (Varieties) } \\
\hline $\mathrm{V}_{1}-\mathrm{MTU} 1010$ & 91145 & 97523 & 94334 & 51595 & 57974 & 54784 & 1.30 & 1.46 & 1.38 \\
\hline $\mathrm{V}_{2}$-Rajendra & 75704 & 80296 & 78000 & 36155 & 40747 & 38451 & 0.91 & 1.03 & 0.97 \\
\hline $\mathrm{V}_{3}$ - Pradyumna & 80483 & 85538 & 83011 & 40933 & 45989 & 43461 & 1.03 & 1.16 & 1.09 \\
\hline $\mathrm{SEm} \pm$ & 882 & 1001 & 940 & 882 & 1001 & 940 & 0.02 & 0.03 & 0.02 \\
\hline $\mathrm{CD}(0.05)$ & 3464 & 3930 & 3690 & 3464 & 3930 & 3690 & 0.09 & 0.10 & 0.09 \\
\hline \multicolumn{10}{|c|}{ Sub treatments(combination of plant density and fertilizer levels) } \\
\hline $\mathrm{T}_{1}-\mathrm{P}_{1} \mathrm{~F}_{1}$ & 63529 & 67851 & 65690 & 27070 & 31392 & 29231 & 0.74 & 0.86 & 0.80 \\
\hline $\mathrm{T}_{2}-\mathrm{P}_{1} \mathrm{~F}_{2}$ & 69686 & 74427 & 72057 & 30941 & 35682 & 33312 & 0.80 & 0.92 & 0.86 \\
\hline $\mathrm{T}_{3}-\mathrm{P}_{1} \mathrm{~F}_{3}$ & 72499 & 76939 & 74719 & 31494 & 35934 & 33714 & 0.77 & 0.88 & 0.82 \\
\hline $\mathrm{T}_{4}-\mathrm{P}_{2} \mathrm{~F}_{1}$ & 77334 & 82267 & 79801 & 40115 & 45048 & 42582 & 1.08 & 1.21 & 1.14 \\
\hline $\mathrm{T}_{5}-\mathrm{P}_{2} \mathrm{~F}_{2}$ & 83293 & 88968 & 86131 & 43788 & 49463 & 46626 & 1.11 & 1.25 & 1.18 \\
\hline $\mathrm{T}_{6}-\mathrm{P}_{2} \mathrm{~F}_{3}$ & 86917 & 92837 & 89877 & 45152 & 51072 & 48112 & 1.08 & 1.22 & 1.15 \\
\hline $\mathrm{T}_{7}-\mathrm{P}_{3} \mathrm{~F}_{1}$ & 90254 & 96402 & 93328 & 52115 & 58263 & 55189 & 1.37 & 1.53 & 1.45 \\
\hline $\mathrm{T}_{8}-\mathrm{P}_{3} \mathrm{~F}_{2}$ & 98115 & 104289 & 101202 & 57690 & 63864 & 60777 & 1.43 & 1.58 & 1.50 \\
\hline $\mathrm{T}_{9}-\mathrm{P}_{3} \mathrm{~F}_{3}$ & 100368 & 106096 & 103232 & 57683 & 63411 & 60547 & 1.35 & 1.49 & 1.42 \\
\hline SEm \pm & 1211 & 1259 & 1233 & 1211 & 1259 & 1233 & 0.03 & 0.03 & 0.03 \\
\hline $\mathrm{CD}(0.05)$ & 3444 & 3580 & 3505 & 3444 & 3580 & 3505 & 0.08 & 0.09 & 0.09 \\
\hline \multicolumn{10}{|l|}{ Interaction } \\
\hline $\mathrm{SEm} \pm(\mathrm{Vx} \mathrm{T})$ & 2166 & 2287 & 2222 & 2166 & 2287 & 2222 & 0.05 & 0.06 & 0.06 \\
\hline $\mathrm{CD}(0.05)$ & NS & NS & NS & NS & NS & NS & $\mathrm{NS}$ & NS & $\mathrm{NS}$ \\
\hline $\mathrm{SEm} \pm(\mathrm{TxV})$ & 2098 & 2181 & 2135 & 2098 & 2181 & 2135 & 0.05 & 0.05 & 0.05 \\
\hline $\mathrm{CD}(0.05)$ & NS & NS & NS & NS & NS & NS & NS & NS & NS \\
\hline
\end{tabular}

$\mathrm{P}_{1}: 25$ hills $/ \mathrm{m}^{2}(20 \times 20 \mathrm{~cm}), \mathrm{P}_{2}: 44$ hills $/ \mathrm{m}^{2}(15 \times 15 \mathrm{~cm}), \mathrm{P}_{3}: 66$ hills $/ \mathrm{m}^{2}(15 \times 10 \mathrm{~cm}) ; \mathrm{F}_{1}: 111-32-45, \mathrm{~F}_{2}: 153-59-68, \mathrm{~F}_{3}: 195-86-90 \mathrm{~kg}$ ha ${ }^{-1}$ 


\section{B:C ratio}

Among the varieties the highest $\mathrm{B}: \mathrm{C}$ ratio was recorded significantly by MTU 1010 (1.30, 1.46 and 1.38 during 2014, 2015 and in pooled means, respectively) over Rajendra and Pradyumna. The lowest B:C ratio was obtained with Rajendra (0.91, 1.03 and 0.97 during 2014, 2015 and in pooled means respectively) (Table 1).

Among the combination of planting density and fertility levels, the highest $\mathrm{B}: \mathrm{C}$ ratio $(1.43,1.58,1.50)$ was observed with the treatment $\left(\mathrm{T}_{8}\right)$ viz., $\mathrm{P} 3(15 \mathrm{~cm} \times 10 \mathrm{~cm})$ in combination with $\mathrm{F}_{2}$ (153-59-68, N, $\mathrm{P}_{2} \mathrm{O}_{5}$ and $\mathrm{K}_{2} \mathrm{O}$ ) during 2014, 2015 and pooled means respectively. It was on par with $\left(\mathrm{T}_{7}\right)$ viz., $\mathrm{P}_{3}$ $(15 \mathrm{~cm} \times 10 \mathrm{~cm})$ in combination with $\mathrm{F}_{1}(111-$ 32-45, N, $\mathrm{P}_{2} \mathrm{O}_{5}$ and $\mathrm{K}_{2} \mathrm{O}$ ) and $\mathrm{F}_{3}$ (195-86-90, $\mathrm{N}, \mathrm{P}_{2} \mathrm{O}_{5}$ and $\mathrm{K}_{2} \mathrm{O}$ ) during 2014, 2015 and pooled means, respectively.

The lowest $\mathrm{B}: \mathrm{C}$ ratio $(0.74,0.86$ and 0.80 during 2014, 2015 and in pooled means, respectively) was obtained with $\left(\mathrm{T}_{1}\right)$ viz., $\mathrm{P} 1$ $(20 \mathrm{~cm} \times 20 \mathrm{~cm})$ in combination with $\mathrm{F}_{1}(111-$ $32-45, \mathrm{~N}, \mathrm{P}_{2} \mathrm{O}_{5}$ and $\mathrm{K}_{2} \mathrm{O} \mathrm{kg} \mathrm{ha}{ }^{-1}$ ).

These results are in agreement with the findings of Swarna (2013) and Dakshina Murthy et al., (2015).

The interaction effect of varieties and plant density in combination with fertility levels during both the years and in pooled mean was found to be non-significant.

\section{References}

Dakshina Murthy, K.M., Upendra Rao, A., Vijay, D and Sridhar, T.V. 2015. Effect of levels of nitrogen, phosphorus and potassium on performance of rice. Indian J. Agricult. Res., 49 (1): 83-87.

Kumar, R.M., Surekha, K., Padmavathi, Ch., Rao, L.V.S., Latha, P.C., Prasad, M.S., Babu, V.R., Ramprasad, A.S., Rupela, O.P., Goud, P.V., Raman, P.M., Somashekar, N., Ravichandran, S., Singh, S.P and Viraktamath, B.C. 2009. Research experiences on system of rice intensification and future directions. $J$. Rice Res., 2: 61-73.

Mohanty, S. 2013. Trends in global rice consumption. Rice Today, Pp. 44-45.

Ologunde, O.O. 1987. Institute of Agriculture research, ABU, Zaria. Samaru Miscellaneous Paper, 118: 4-6.

Perin, R.K., Donald. L.W., Edwards, R.M and Jack, R.A. 1979. From Agronomic data for farmer recommendations. $A n$ Economic Training Manual, CIMMYT Information Bulletin. 27: 15-33.

Singh, R.K and Namdeo, K.N. 2004. Effect of fertility levels and herbicides on growth, yield and nutrient uptake of directseeded rice (Oryza sativa). Indian $J$. Agronomy. 49(1):34-36.

Swarna, R.2013. Evaluation of CERES-Rice model under variable nitrogen levels and plant densities. M.Sc. (Ag.) Thesis. Acharya N G Ranga Agricultural University, Hyderabad, India.

\section{How to cite this article:}

Sampath, O. and Srinivas, A. 2017. Economics of Rice Varieties as Influenced by Combination of Plant Densities and Fertilizer Levels under Late Sown Conditions. Int.J.Curr.Microbiol.App.Sci. 6(7): 17-21. doi: https://doi.org/10.20546/ijcmas.2017.607.003 